\title{
An Overview of the Tourism Economic Effect in the European Union Member States
}

\author{
Gordana PetrovićA, Darjan KarabaševićA , Svetlana VukotićA, Vuk Mirčetić A $^{*}$ \\ Received: May 2020 | Accepted: July 2020 \\ DOI: $10.5937 /$ turizam24-26469
}

\begin{abstract}
Tourism has a notable role in the economies of many countries, and particularly in the countries of the European Union, which are still one of the world's most recognized and visited tourist destinations. The paper aims to analyze the impact of the tourism industry on the economy of the European Union. In this context, the paper is based on research and literature review, in particular, statistics data of Eurostat and the World Travel and Tourism Council. The results achieved by the tourism industry are reflected through certain economic indicators: GDP, employment rate, income, the balance of payments, turnover and consumption. The research area is one of the most visited tourist destinations in the world, which generates significant tourist turnover and justifies the status of an extremely important determinant of economic development. The well managed tourism industry complements other economic activities and increases the income of each EU Member State, and the tourism industry has direct and indirect, positive and negative economic effects.
\end{abstract}

Keywords: Tourism industry, tourist destination, economic effects, European Union.

\section{Introduction}

Tourism, as a social and economic phenomenon, economic activity, is most directly exposed to constant and vigorous changes throughout the world. During the development, tourism simultaneously offered new forms of travel, arrangements, new destinations, and created a need for innovative forms of organizing, new resources and strategies. In addition to dynamism, another dominant feature is a mass phenomenon. Tourism is present as an occurrence in all countries but is different in its scope and effects. Petrović et al. (2016) state that tourism is an economic activity that covers the travels with no business character. Many economic activities are involved in the process of meeting the needs of tourists. Therefore, tourism is undoubtedly a significant segment of a country's economic development (Petrović et al., 2018). Besides, tourism is a fast-growing services sector in emerging countries (Faber, Gaubert, 2019; Roudi et al.,

A University Business Academy in Novi Sad, Faculty of Applied Management, Economics and Finance, Jevrejska24, 11000 Belgrade, Serbia; Corresponding author: vuk.mircetic@mef.edu.rs 
2019). The tourist market and tourist traffic are categories that are changing and constantly evolving and therefore, have taken on unprecedented proportions (Čerović, 2002, p. 21).

Tourism plays a vital role in the economies of many countries, and especially in the countries of the European Union, which is still one of the world's most famous tourist destinations. For a large number of European Union member states, tourism is a significant driver of the national economy. It provides economic development of countries and regions, but it also contributes to their social, cultural development and general well-being. One of the most important functions of tourism is that it, directly and indirectly, influences GDP growth. The tourism sector has significantly grown in recent decades. In this regard, the tourism industry has become one of the essential tools for achieving sustainable economic growth in most countries. The tourism sector is not only is a significant contributor to the increase of GDP, but it also plays a vital role in terms of providing employment opportunities, reducing poverty, increasing of the income distribution, generating additional demand for goods and services, providing additional tax revenues and foreign exchange reserves for the governments (Taizeng et al., 2019).

Europe is the number one tourist destination in the world with a market share of 50\% in 2016 (World Tourism Organization, 2017). The tourism industry generated (directly and indirectly) 10.2\% of total GDP in the European Union, with a projection to grow to 11.2\% of GDP by 2027 (Internet 1).

Tourism plays a significant role in the economy of the European Union. According to the European Commission, it is the third-largest socio-economic activity in the Union (after trade and distribution, as well as the construction industry) and has an overall positive impact on economic growth and employment rate. Tourism also contributes to the development of the European region and, if it is sustainable, helps to preserve and improve cultural and natural heritage (European Parliamentary Research Service, 2015, p. 5). The European Union covers $40 \%$ of international tourist arrivals and $31 \%$ of international tourism income (World Tourism Organization, 2018, p. 17). According to the statistics from 2016, the population of the European Union was estimated to be 509 million inhabitants, accounting for $7 \%$ of the world's population. The territory is after China ( 1.4 billion) and India ( 1.3 billion) the third most populous in the world (World Tourism Organization, 2018, p. 12).

It can be said that there are no specific methods and techniques of research in tourism (or tourism research) as an economic activity, but rather, general research methods and techniques are used. Research in tourism accepts the above classifications, but they also have certain specificities, since the tourism industry itself is specific. Considering that the development aspects of tourism are reflected through consumption and that tourism is essentially an economy, general tourism research uses economic analysis methods to explain and understand social and economic phenomena in tourism (Vujović, 2019, p. 4).

Most European countries have a well-established system of statistics to track tourism demand in terms of domestic and outbound travel, tourist accommodation and costs. The research in this paper presents an analysis of data for the period from 2010 to 2019 collected by Eurostat and the World Travel and Tourism Council. Additionally, their publications for 2016 and 2017, which were published in 2018 and 2019 were also used.

The main aim of the paper is to analyze the impact of the tourism industry on the economy of the European Union. In this context, the paper is based on research and literature review, in particular, statistics data of Eurostat and the World Travel and Tourism Council.

The paper has, in addition to the introduction and conclusions, thematic sections that relate to economic indicators in the tourism industry in EU countries, then spending on tourism trips in EU countries, and the impact of tourism on GDP growth. The paper is intended for the interested professional and scientific public. 


\section{Tourism industry economic indicators in European Union countries}

Tourism is classified as an important economic category. Tourism is an area of the economy which includes various industries and branches. The activities are aimed at providing services that enable tourists to meet their tourist needs, and on that basis, they are given a tourism sign, and together they constitute the tourism economy (Ilić et al., 2016, p. 201). Tourism is evolving, introducing new consumer needs and preferences. The quality of marketing activities significantly influences the branding of tourism organization services (Brzaković, Brzaković, 2018). The classical division into countries of tourist supply and tourist demand has been overcome longtime ago. Many tourist demand countries earn much more from tourism than tourist supply countries. Certain elements condition the orientation of tourist movements towards particular destinations. The uneven development of tourism in different regions of the world points to the exceptional importance of Europe (Vujović et al., 2012, p. 41). The economic analysis of the tourism industry in EU countries, according to Eurostat (data for 2016, published in 2019), takes into consideration four indicators. Those are:

1. Number of enterprises,

2. Number of employees,

3. Turnover and

4. Value added at factor cost - first at EU level and second at country level.

Tourism is of particular importance, primarily because of its impact on the country's pay balance and the multiplier effects of foreign tourists' consumption. Because it is a very significant source of foreign exchange, tourism is classified as favoured export branches (Cvijanović et al., 2017). Increase in tourist traffic and consumption of foreign and domestic tourists leads to the involvement of a large number of workers in the tourism industry. Moreover, the number of employees in non-business activities, which directly participate in meeting the needs of tourists, is also increasing (Njegovan, 2016, p. 47). In 2016, 10\% of businesses in the European non-financial business economy belonged to the tourism industries. In those 2.4 million enterprises, 13.6 million people were employed. Enterprises from industries related to tourism accounted for $9.5 \%$ of persons employed in the non-financial business economy and $21.7 \%$ of persons employed in the services sector. The largest number of employees in the tourism industry among EU countries is in Germany $(2,452,086)$, the United Kingdom $(2,294,679)$, Italy $(1,498,798)$ and Spain $(1,435,465)$.

Table 1. Key economic indicators for the tourism industry and percentages, EU-28 for 2016

\begin{tabular}{|l|c|c|c|c|}
\hline & $\begin{array}{c}\text { Number of } \\
\text { enterprises }\end{array}$ & $\begin{array}{c}\text { Turnover } \\
\text { (million EUR) }\end{array}$ & $\begin{array}{c}\text { Value added at factor } \\
\text { cost (million EUR) }\end{array}$ & $\begin{array}{c}\text { Number of persons } \\
\text { employed }\end{array}$ \\
\hline $\begin{array}{l}\text { Share of total tourism industry in total non- } \\
\text { fiscal business economy (\%) }\end{array}$ & $10.0 \%$ & $3.9 \%$ & $5.8 \%$ & $9.5 \%$ \\
\hline $\begin{array}{l}\text { Share of total tourism industry in total } \\
\text { services (\%) }\end{array}$ & $19.9 \%$ & $16.3 \%$ & $14.0 \%$ & $21.7 \%$ \\
\hline Transport related total (\%) & $15.9 \%$ & $26 \%$ & $25.7 \%$ & $16.1 \%$ \\
\hline Accommodation (\%) & $13.2 \%$ & $16.8 \%$ & $20.9 \%$ & $19.7 \%$ \\
\hline Food and beverage (total) (\%) & $64.0 \%$ & $33.6 \%$ & $35.5 \%$ & $58.7 \%$ \\
\hline Car and other rental (total) (\%) & $2.3 \%$ & $7.7 \%$ & $9.9 \%$ & $1.6 \%$ \\
\hline $\begin{array}{l}\text { Travel agency, tour operator reservation } \\
\text { service and related activities (total) (\%) }\end{array}$ & $4.5 \%$ & $15.9 \%$ & $8.0 \%$ & $3.8 \%$ \\
\hline
\end{tabular}

Source: Internet 2 
Tourism is the largest generator of wealth and employment in the world. Tourism is an economic engine for developed and developing economies around the world (Rita, 2000, p. 434). Employment in the tourism industry in the field of transport is $16.1 \%$. Most employees among EU members are in Germany $(297,070)$, the United Kingdom $(282,110)$ and Italy $(178,802)$. Employees in the accommodation facilities account for $19.7 \%$ of the tourism industry. Most of them are employed in Germany $(569,418)$ and the United Kingdom $(447,436)$. The food sector, by the number of employees in the tourism industry, accounts for the highest share of $58.7 \%$. The least employees are in car rental (1.6\%) and travel agencies (3.8\%) (Internet 3).

Revenues are the result of regular business operations of the company, and they are generated in the market by selling products and services. The income of the company primarily depends on demand, that is, the desire and ability of consumers to buy a certain amount of products and services. For an enterprise, demanded amount of products and services is the amount that an enterprise can offer and sell on the market and generate income. Revenue is an indicator of the efficiency of the company, but it is also a condition for its survival. Without revenue generation, a company are not able to survive in the market (Pokrajčić, 2008, p. 27). In tourism, the quality of the visitor experience depends not only on the attraction of the primary attractions (beaches or historical sites) but also on the quality and effectiveness of complementary businesses, such as hotels, restaurants, distributors and transport facilities (Mirčetić et al., 2019).

Data for 2016 show that $10 \%$ of enterprises in the non-financial business economy belong to the tourism industry, which generates $3.9 \%$ of tourist turnover, $5.8 \%$ of the additional value of the non-financial business economy, which employs $9.5 \%$ in the non-financial business economy. Tourism as an economic sector belongs to the service sector, and by the number of enterprises $(2,444,841)$ in the sector, the tourism industry participates with $19.9 \%$.

The transport industry is vital for the functioning of tourism, and $15.9 \%$ of transport companies are engaged in the tourism industry. Among EU Member States, the most transport companies is concentrated in France $(60,604)$, Poland $(46,194)$, Greece $(36,311)$, Italy $(30,311)$ and Germany $(28,022)$ (Internet 4$)$. In the tourism industry, $13.2 \%$ are companies dealing with tourist accommodation. Most companies in the accommodation sector are located in France $(51,583)$, Italy $(49,417)$ and Germany $(44,221)$. Most businesses are engaged in the food sector $(64.0 \%)$. Italy $(269,955)$, Spain $(267,049)$ and France $(207,138)$ hold a leading position among EU member states.

Least enterprises $(2.3 \%)$ in the tourism industry are engaged are in renting industry (cars and other vehicles). The EU member states with most car rental companies are France (12,091), United Kingdom $(5,368)$, Germany $(5,281)$, Spain $(4,940)$ and Italy $(4,802)$.

Travel agency and tour operators account for $4.5 \%$ of the overall travel industry. In this branch, Italy $(16,800)$, Spain $(12,932)$ and Germany $(12,339)$ are in the leading position among EU member countries. When it comes to the total amount of enterprises in the tourism industry $(2,444,841)$ among the EU Member States, the leading countries are Italy $(371,285)$, France $(340,345)$, Spain $(314,399)$ and Germany $(258,521)$. Of the total number of enterprises in the tourism industry, $52.5 \%$ of tourism enterprises are located in these countries.

Tourism traffic, as an indispensable component of tourism development, represents an indicator that determines the total number of tourists and the number of their overnight stays in an area, that is, synthetically and summary indicator of extent, dynamics and structure of tourist movements. In order to get a complete picture of tourist traffic in the selected area, tourist traffic is observed through movement and staying of tourists and through the utilization of existing tourist and catering capacities (Omerović, 2014, p. 174). 
The total turnover of the tourism industry in the services sector is $16.3 \%$. Transport related turnover of the tourism industry accounts for $26 \%$, and almost half of which is achieved by air transport (12.4\%). The most substantial turnover in the tourist industry is realized through the supply of tourists with food and beverages and amounts to $33.6 \%$, followed by the turnover through accommodation capacities (16.8\%), the tourist agencies and tour operators (15.9\%), while the lowest turnover is through car rental (7.7\%).

The most significant turnover in the EU Member States in the entire tourism industry was in the United Kingdom (229.118 million Euros), Germany (154.367 million Euros), France (140.251 million Euros), Italy (117.382 million Euros) and Spain (104.277 million Euros), (Internet 5).

The tourism industry is involved in creating added value in the services sector by $14.0 \%$. In the tourism industry, the transport sector achieves an added value of $25.7 \%$, accommodation $20.9 \%$, car rental sector 9.9\%, travel agencies and tour operators $8.0 \%$, while the highest added value in the tourism industry is achieved by the food industry (food and drink), and its share is $35.5 \%$.

Comparing the EU Member States in the tourism industry, the highest added value is achieved by the United Kingdom ( 97,532 million Euros), Germany (61,023 million Euros), France (53,287 million Euros), Italy (43,795 million Euros) and Spain (37.801 million Euros). Of all EU Member States, the United Kingdom generated the highest added value in the tourism industry is in several sectors, transport (18,282 million Euros), lodging (15,830 million Euros), food and drink (34,796 million Euros) and car rentals (14,366 million Euros), travel agencies and tour operators (14,258 million Euros)(Internet 6).

The most important economic characteristic of activities related to the tourism sector is that they contribute to revenue, employment and profits. In this respect, the tourism sector can play an essential role as a driving force for economic development. The impact that the tourism industry can have at different stages of economic development depends on the specific characteristics of each tourist area. Given the complexity of tourism consumption, its economic impact is widely felt in other productive sectors and undoubtedly contributes to the achievement of goals for faster development.

\section{Tourist trips expenditures in European Union member states}

Eurostat data (Internet 7) shows that in 2017 EU residents spent 467 billion Euros on tourist travel and overnight stays, of which $44 \%$ are expenses in domestic tourism and $56 \%$ of costs in tourism that takes place outside borders of the residence country. In absolute terms, German (129 billion), French ( 82 billion) and British (61 billion) tourists spent the most. Their expenditures total about $59 \%$, while they account for $50 \%$ of the total number of trips and $53 \%$ of the total nights spent.

Among EU member states, residents of France spend the most on domestic tourism (54 billion Euros). They are followed by residents from Germany ( 42 billion Euros), Spain ( 25 billion Euros) and the United Kingdom (23 billion Euros). Citizens of Germany spend most outside of their borders ( 87 billion Euros). Residents of the United Kingdom are the next in line ( 38 billion Euros), followed by citizens from France ( 28 billion Euros) and Holland (18 billion Euros) (Internet 8).

Average tourist spending of EU residents is 377 Euros per trip, of which domestic tourists spend 223 Euros, while tourists travelling abroad spend on average 812 Euros. The aver- 
Total tourism spending in EU (2017)

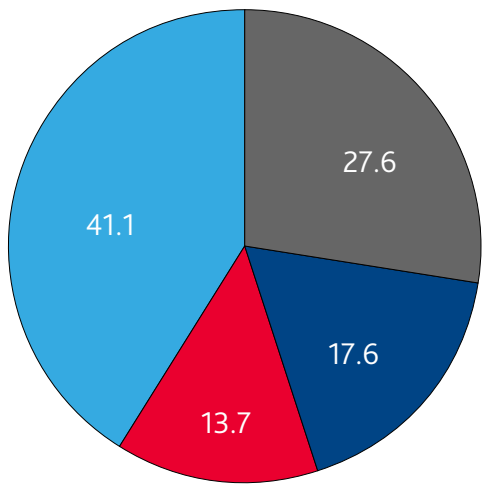

Germany
Tourist spending in domestic tourism

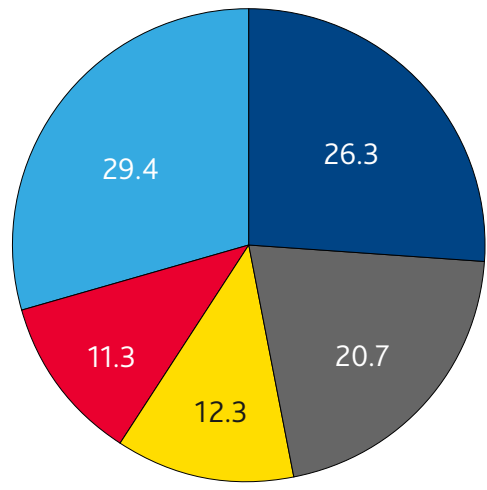

United Kingdom
Tourist spending outside the borders of own country

Figure 1. Total tourism spending, domestic tourists consumption and EU foreign tourists consumption in 2017 (consumption expressed in\%) Source: Author processing based on Internet 7

age spending per tourist per night is 75 Euros, where domestic tourists spend an average of 58 Euros and tourists travelling abroad spend approximately 97 Euros.

Of the total cost of tourist trips (domestic and foreign tourists), the most is spent by the citizens of Luxembourg (769 Euros), followed by Austrians (641 Euros), Maltese (633 Euros), Danes (618 Euros) and Cypriots (6oo Euros). Domestic tourists' expenditure per trip is the highest among Austrians (371 Euros), Danes (351 Euros) and Italians (331 Euros). The most significant average expenditures per trip outside their home country are made by the Danes (EUR 1,279), the Cypriots (EUR 1,059) and the French (EUR 1,00o).

In 2017, EU residents made 1.3 billion overnight stays, which amounted to almost 6.4 billion overnight stays. The average duration of the trip was 5.1 overnight stays. Compared to 2016, the number of tourist trips by EU residents increased by $4 \%$. Almost three quarters (73\%) of all trips were made in the country of residence (domestic travel), while slightly more than one quarter (27\%) were abroad trips (abroad travel), of which $21 \%$ went to other EU countries and $6 \%$ to destinations outside the EU.

The most common mode of transport for travel were private or rented motor vehicles (predominantly cars) (64\%), followed by aeroplanes (17\%), trains (11\%), buses (6\%) and water vessels (2\%).Aeroplanes served as the primary mode of transport for over half of abroad trips (56\%), while for domestic trips EU residents travelled mainly by vehicles $(76 \%)$, followed by trains (13\%). The majority of air travel was for personal reasons $(82 \%)$, while the remaining $18 \%$ of air travel was for professional purposes (EUROSTAT, 2019, p.1).

In total overnight stays (domestic and foreign tourists), the most significant average expenditures per capita are those made by residents of Denmark (162 euros), Austria (132 euros), Malta (128 euros) and Ireland (112 euros). Domestic tourists spend the most in Denmark (136 Euros), Austria (112 Euros) per overnight stay, while tourists travelling outside the borders of their country spend the most per overnight stay are from Denmark (186 Euros), Finland (148 Euros), Austria (142 Euros) and France (128 euros)(Table 1). 

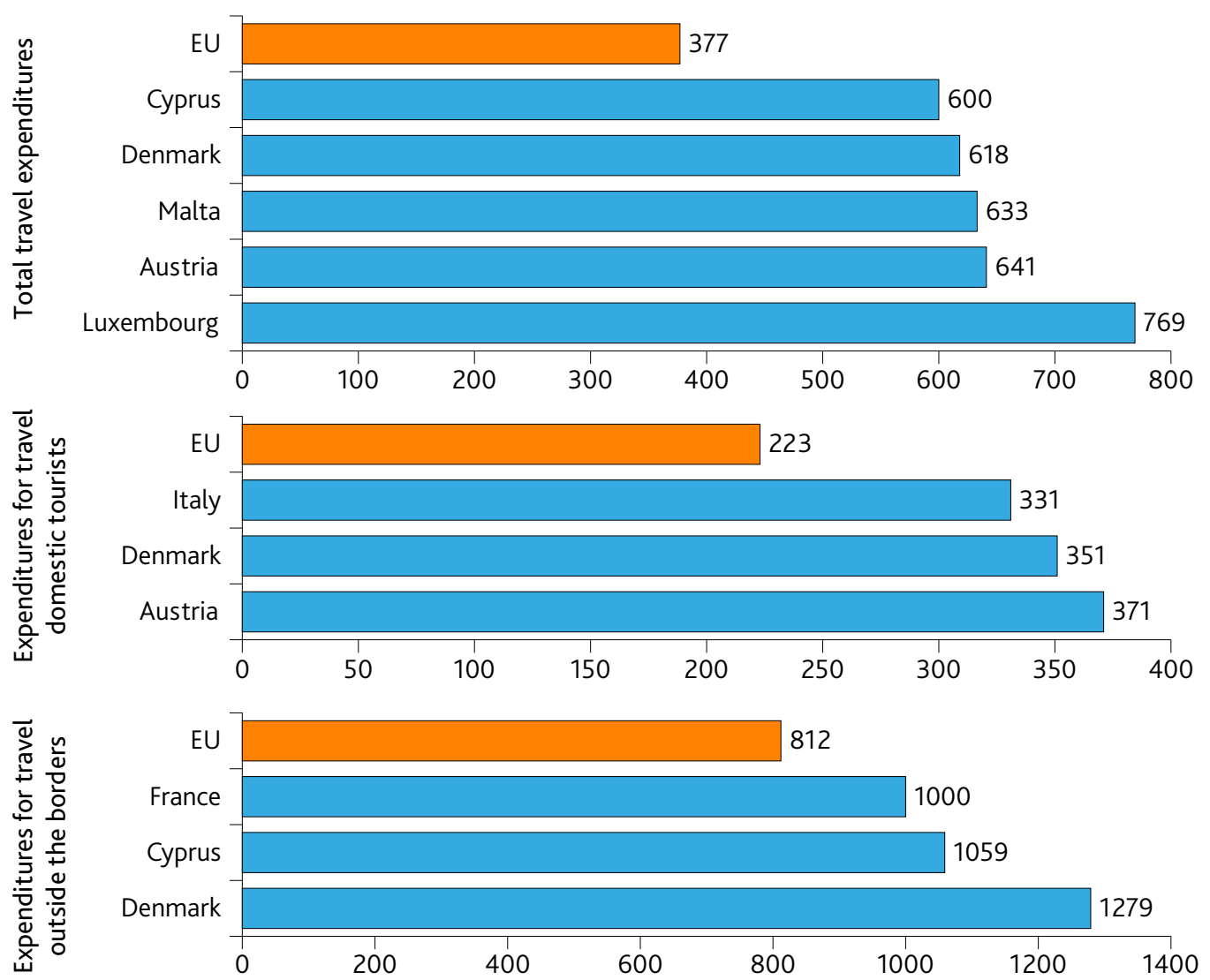

Figure 2. Total travel costs to the EU, countries spending the most per trip - costs for locals and tourists and costs for tourists traveling outside their own country

Source: Author processing based on Internet 10

In the EU Member States, of the total travel expenses for travel, the largest share in domestic tourism is achieved by Romanians 79\%, Greeks 76\%, Spaniards 66\%, French and Portuguese $65 \%$ and Bulgarians and Italians 64\%. In total travel, Luxembourg's 99\%, Belgium's 93\% and Malta's 92\% spend the most outside their country's borders (Figure3).

"The global tourism market is experiencing strong growth along a steep upward trajectory. The World Tourism Organization predicts an unprecedented total of 1.5 billion international travelers in 2020, with European countries remaining the most visited destinations." (Sriboonjit et al., 2010, p 422). Tourism is often advocated as a tool for improvement of broader international integration in areas such as the European Union or as a catalyst for modernization, economic development and prosperity in the development of new third countries (Williams, 1998, p.1). Growth in Europe has been slower than in previous years (+ 4\%), and notwithstanding, Europe continues to lead in terms of international arrivals, reporting 743 million international tourists in 2019, accounting for $51 \%$ of the global market (Internet 9). Tourism as an economic, social and cultural activity is one of the most significant activities of modern society and global economic development and is of particular importance in European countries. 

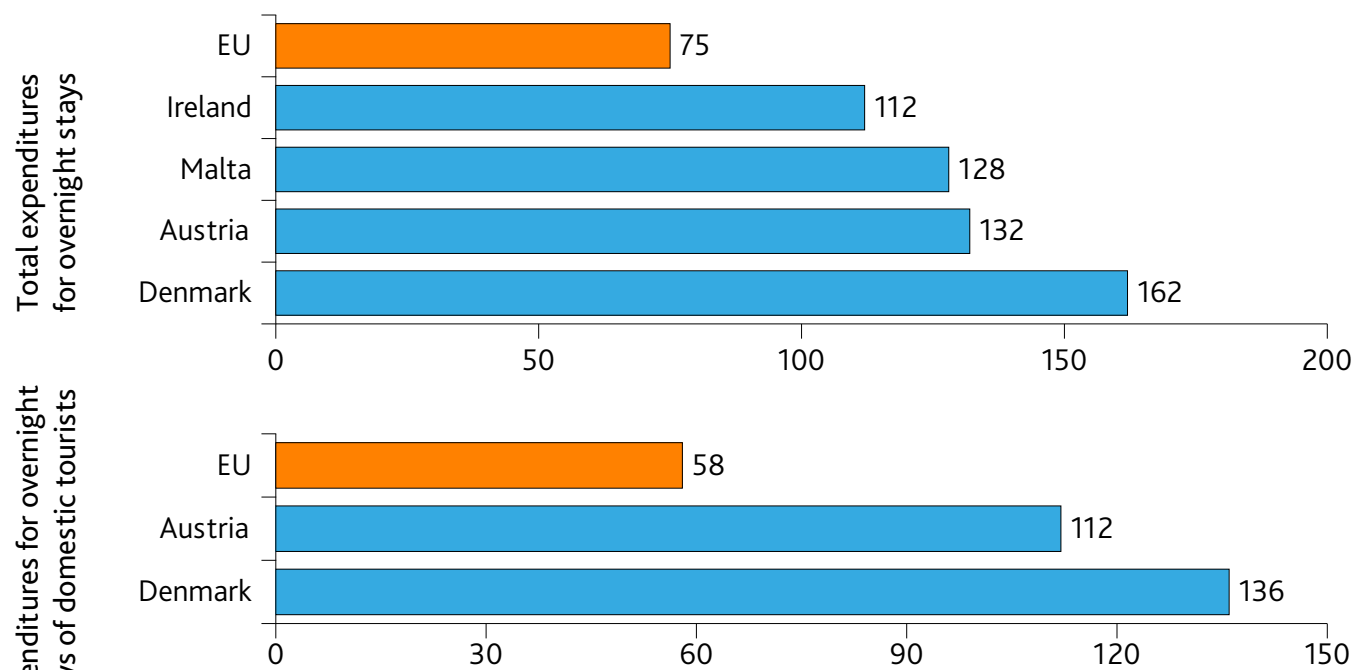

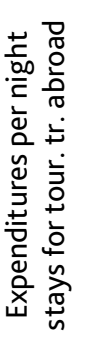

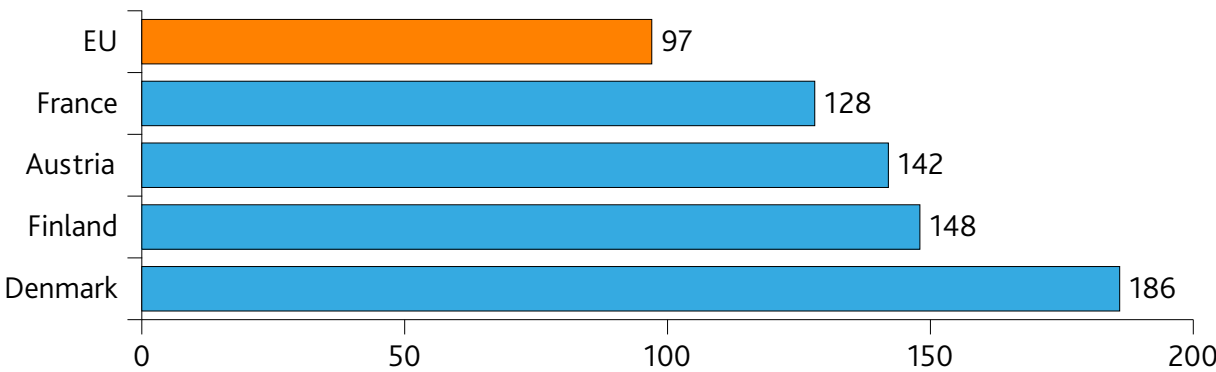

Figure 3. Total spending on overnight stay accommodation in the EU, countries spending the most per overnight stay- domestictourists and tourists traveling abroad Source: Data processing by authorsbased on Internet 7

\section{Impact of tourism on GDP growth}

The impact of tourism on economic development has led to the emergence of a concept called "tourism-driven development". As a result, the tourism industry has become a key sector of the European economy (Lee, Brahmasrene, 2013). Roman et al. (2020, p. 1) state that "tourism is the third largest socio-economic activity in the EU, and it makes an important contribution to the EU's gross national product and employment." Also, it should be emphasized that the Europe is the world's number one tourist destination (Sokhanvar, 2019).

Tourism is an essential economic activity in the EU in terms of GDP, employment and foreign trade. Statistics (Internet 10) show that the total share of the tourism sector in global GDP in 2019 was 9.4\%, while the direct impact of tourism on world GDP in the same year it was $3.7 \%$, which classifies tourism as one of the most profitable economic activity worldwide. During holidays, most countries want to profit by selling their tourism potential, therefore stimulating a large number of tourists to spend. The size of tourism and its quality contains numerous activities that are formed and linked horizontally and vertically with other sectors of the production industry, which significantly affects the growth of their economies (Zurub et al., 2015). 
Table 2. Total and direct contribution of tourism and travel to GDP in the European Union

\begin{tabular}{|l|c|c|c|c|c|c|c|c|c|c|}
\hline Tourism and travel & $\mathbf{2 0 1 0}$ & $\mathbf{2 0 1 1}$ & $\mathbf{2 0 1 2}$ & $\mathbf{2 0 1 3}$ & $\mathbf{2 0 1 4}$ & $\mathbf{2 0 1 5}$ & $\mathbf{2 0 1 6}$ & $\mathbf{2 0 1 7}$ & $\mathbf{2 0 1 8}$ & $\mathbf{2 0 1 9}$ \\
\hline Total contributionto GDP(\%) & 8.6 & 8.8 & 9.0 & 9.1 & 9.0 & 9.2 & 9.1 & 9.3 & 9.3 & 9.4 \\
\hline Direct contribution to GDP(\%) & 3.3 & 3.4 & 3.5 & 3.5 & 3.6 & 3.6 & 3.6 & 3.7 & 3.7 & 3.7 \\
\hline
\end{tabular}

Source: Internet 10

The particularly high indirect contribution of tourism to GDP indicates that tourism has the potential to make a significant contribution to growth in all countries. However, the extent and effectiveness of this contribution, especially where it is indirect, depends on the tourism promotion policies implemented in each country. Tourism development requires significant investments, which often leads to a comparison of tourism with heavy industry in terms of public and private investment in the infrastructure such as road and transport networks, distribution of drinking water, waste treatment, access to the electricity network and new communication systems (Petković, Pindžo, 2012, p. 119).

According to relevant sources, tourism standardly contributes to the European Union (EU) gross domestic product (GDP) by over $9 \%$. It is one of the vital activities and has an impressive impact on the economic growth of the European Union (EU), on employment and accelerated social development, which means that it is a safe tool to combat the economic downturn, but also significantly reduce the unemployment rate (Totić, 2017, p. 399). Data from the last several years, from the World Travel and Tourism Council (WTTC), show that tourism is a growing industry. Total tourism share (Table 2) in GDP in the observation period ranges from 8.6\% (2010) to 9.4\% (2019). The direct impact of tourism on GDP also recorded a growth trend of $3.3 \%$ (2010) to $3.7 \%$ (2019).

The most significant direct and indirect share of tourism in GDP during the observed period (2010-2019) is in Croatia. Its direct share of tourism in GDP ranges from 8.4\% (2010) to 11.0\% (2019). Total tourism share is significantly higher, from $20.3 \%$ in 2010 up to $25.1 \%$ in 2019. It can be concluded that Croatia is above the EU average in terms of tourism's share of GDP, as it "continues to reap the benefits of the successful rebuilding of its tourism sector over the last decade. In 2016, arrivals grew $9 \%$ for the second year in a row, to a total of 14 million, enhanced by increased air connectivity. Receipts grew in line with arrivals (+8\%) to a total of euro 9 billion." (UNWTO, 2019, p. 24).

Croatia, which is convincingly ahead of all EU member states in terms of tourism's share of GDP, is followed by Greece and Cyprus, where "arrivals in Greece grew 5\% in 2016 to a total of 25 million. Growth peaked towards the end of the year, recovering from a decrease in arrivals during the first part of the year due to the refugee and migrant crisis, while tourism receipts fell by $7 \%$ to euro 13 billion. Cyprus $(+20 \%) 3$ million arrivals in 2016, receipts for this destination grew accordingly, with Cyprus earning euro 3 billion (+11\%) (UNWTO, 2019, p. 24).

The lowest share of tourism in GDP of all EU member states, if viewed in the period from 2017 to 2019 has Lithuania (1.8-1.9\%), Netherlands (1.7\%) and Romania, and the least direct values are in Romania (1.4-1.5\%). The lowest share of the total value of tourism in GDP has Poland (4.5\%), Lithuania (4.9-5.0\%) and the Netherlands (5\%).

If Serbia is observed in the period from 2010 to 2019, the direct participation of tourism in GDP is increasing, but it is below the European average and ranges from $1.8 \%$ to $2.4 \%$. Total share in GDP is also growing, ranging from $5.1 \%$ to $6.9 \%$. Tourism is one of the important economic activities in Serbia, and its successful development represents the basis for the development of other economic activities that would contribute to its inclusion in the European and world tourist flows. Also, Serbia is rich in natural resources, which can provide an excellent comparative advantage in the tourism market (Urošević et al., 2018). 



Figure 4. Direct and total share of tourism in GDP in Croatia, Greece, Cyprus and Serbia 2010-2019 Source: Author processing based on Internet 10

\section{Conclusion}

It is believed that with a higher degree of economic development in a country, the importance of the service sector is increasing. Also, the service economy is taking over and, it is becoming a reality, not only a projection. Tourism, as a complex economic activity, represents a crucial role in development for many countries in the world. The tourism sector also plays a significant role in the economic growth of the European Union, mainly in terms of revenue, GDP, employment creation and economic growth. Europe is a popular tourist destination. The whole range of natural beauties, as well as its traditional cultural heritage, plays a vital role in the further development of the tourism industry. Tourism plays an essential role in the economies of the European Union, which is still one of the world's most famous tourist destinations.

According to the European Commission, it is the third-largest socio-economic activity in the Union (after trade and distribution, as well as construction) and has an overall positive impact on economic growth and employment. In 2016, 10\% of businesses in the European non-financial business economy belonged to the tourism industries. These 2.4 million businesses employ 13.6 million people. Enterprises from the tourism industry accounted for $9.5 \%$ of persons employed in the non-financial business economy and $21.7 \%$ of persons employed in the services sector.

The most employees in the tourism industry among EU countries is in Germany $(2,452,086)$, the United Kingdom $(2,294,679)$, Italy $(1,498,798)$ and Spain $(1,435,465)$.

Research shows that a considerable number of workers are involved in the tourism industry and the consumption of foreign and domestic tourists in the tourism industry. Moreover, the number of employees in non-business activities, which directly participate in satisfying the needs of tourists, is increasing.

The total turnover of the tourism industry in the services sector is $16.3 \%$. Transport related turnover of the tourism industry accounts for $26 \%$, and almost half of which is achieved by 
air transport (12.4\%).The most substantial turnover in the tourist industry is realized through the supply of tourists with food and beverages and amounts to $33.6 \%$, followed by the turnover through accommodation capacities (16.8\%), the tourist agencies and tour operators (15.9\%), while the lowest turnover is through car rental (7.7\%).

The most important economic characteristic of activities related to the tourism sector is that they contribute to revenue generation, so in this respect, the tourism sector plays a crucial role as a driving force for economic development. The highest added value is achieved by the United Kingdom (97,532 million Euros), Germany (61,023 million Euros), France (53,287 million Euros), Italy (43,795 million Euros) and Spain (37.801 million Euros).The impact that the tourism industry has at different stages of economic development depends on the specific characteristics of each tourist area. Given the complexity of tourism spending, its economic impact is widely felt in other sectors of the economy and contributes in any case to the achievement of the goals of faster development. In 2017, EU residents spent a total of 467 billion Euros on tourist travel and overnight stays, of which $44 \%$ are expenses in domestic tourism, and $56 \%$ are expenses of tourism outside the country of origin. In absolute amount, German (129 billion), French ( 82 billion) and British (61 billion) tourists spent the most. Their expenditures amount to around $59 \%$ in total, while they account for $50 \%$ of the total number of trips and $53 \%$ of total overnight stays.

Data for the period from 2010 to 2019 shows that tourism is a growing industry. In the observation period, total tourism share in GDP ranges from 8.6\% (2010) to 9.4\% (2019). The direct impact of tourism on GDP also recorded a growth trend of 3.3\% (2010) to $3.7 \%$ (2019). The most significant direct and indirect share of tourism in GDP is in Croatia.

The global tourism market is experiencing strong growth and is moving upward. The World Tourism Organization expects a total of 1.5 billion international travellers in 2020, leaving Europe the most visited tourist destination.

As a direction for future research, econometric methods such as Granger causality test or Johansen test could be used to examine tourism economic effects in the EU.

\section{References}

Brzaković, A., Brzaković, T. 2018. Brand as a Factor of Business Success of the Tourist Organization. In: 3rd International Scientific Conference Tourism in function of development to the Republic of Serbia-Tourism in the Era of Digital Transformation, Thematic Proceedings, (640-656). Vrnjačka Banja: Faculty of Hotel Management and Tourism with co-organizers.

Čerović, S. 2002. Strategic Management of the Serbian Tourist Economy. Belgrade: Singidunum University. (in Serbian)

Cvijanović, D., Vukotić, S., Vojinović, Ž. 2017. The most important economic effects of tourism in Serbia and worldwide. In: Sustainable Development of Tourism Market - International Practice and Russian Experience, (15-19). Russia: Stavropol State Agrarian University.

European Parliamentary Research Service. 2015. Tourism and the European Union.

EUROSTAT. (2019). Three quarters of all trips by EU residents are within their own country.

Faber, B., \&Gaubert, C. 2019. Tourism and economic development: evidence from Mexico's coastline. American Economic Review 109(6), 2245-93.

Ilić, D., Marinoski, N., Djeri, L., Stamenković, P. 2016. Basics of tourism theory and practice. Leskovac: Higher Business School of Professional Studies. (in Serbian) 
Lee, J. W., Brahmasrene, T. 2013. Investigating the influence of tourism on economic growth and carbon emissions: Evidence from panel analysis of the European Union. Tourism management 38, 69-76.

Mirčetić, V., Vukotić, S., Cvijanović, D. 2019. The Concept of Business Clusters and its Impact on Tourism Business Improvement. Economics of Agriculture 66(3), 851-868.

Njegovan, Z. 2016. Economics of tourism and rural tourism. Novi Sad: Faculty of Agriculture. (in Serbian)

Omerović, J. 2014. Tourism traffic as an indispensable component of tourism development in Tuzla. Zbornik radova Departmana za geografiju, turizam I hotelijerstvo 43(2), 174-184. (in Bosnian)

Petković, G., Pindžo, R. 2012. Tourism and new economic challenges. Journal of the Serbian Association of Economists 6o(1-2), 117-126.

Petrović, G., Karabašević, D., Maksimović, M. 2016. Tourist traffic and revenue from tourism in the Republic of Serbia. Ekonomski signali 11(2), 61-75.

Petrović, G., Maksimović, M., Karabašević, D. 2018. Strategic positioning of rural tourism on Staraplanina. Economics of Agriculture 64(2), 601-617.

Pokrajčić, D. 2008. Economics of Enterprises. Belgrade: Faculty of Economics. (in Serbian)

Rita, P. 20oo. Tourism in the European Union. International Journal of Contemporary Hospitality Management 12(7), 434-436.

Roman, M., Roman, M., Niedziółka, A. 2020. Spatial Diversity of Tourism in the Countries of the European Union. Sustainability 12(7), 2713.

Roudi, S., Arasli, H., Akadiri, S. S. (2019). New insights into an old issue-examining the influence of tourism on economic growth: evidence from selected small island developing states. Current Issues in Tourism 22(11), 1280-1300.

Sokhanvar, A. 2019. Does foreign direct investment accelerate tourism and economic growth within Europe? Tourism Management Perspectives 29, 86-96.

Sriboonjit, J., Chaovanapoonphol, Y., Wiboonpongse, A., Calkins, P., Sriboonchitta, S. 2010. Economic Determinants of Long-Term Equilibrium in Malaysian Tourist Arrivals to Thailand: Implications for Tourism Policy. International Journal of Intelligent Technologies and Applied Statistics 3(4), 421-435.

Taizeng, R., Muhlis, C., Sudharshan, Reddy, P., Jianchun, F., Wanshan, W. 2019. The Impact of Tourism Quality on Economic Development and Environment: Evidence from Mediterranean Countries. Sustainability 11(8), 2296.

Totić, M. 2017. Legal support for the development of tourism in the European Union. In: 4th International Scientific Conference Agribusiness MAK-2017. Kopaonik: Municipality of Raška with co-organizers. (in Serbian)

UNWTO. 2019. European Union Tourism Trends. Madrid.

Urošević, S., Stanujkić, D., Karabašević, D., Brzaković, P. 2018. Using single valued neutrosophic set to select tourism development strategies in eastern Serbia. Economics of Agriculture 65(2), 555-568.

Vujović, S. 2019. Tourism development in the light of certain theoretical and methodological researches. Belgrade: Economics Institute. (in Serbian)

Vujović, S., Štetić, S., Cvijanović, D. 2012. Destination concept of tourism development. Belgrade: Institute of Agricultural Economics. (in Serbian)

Williams, S. 1998. Tourism Geography. London and New York: Routledge.

World Tourism Organization 2017. Tourism Highlights 2017 Edition. Madrid.

World Tourism Organization. 2018. European Union Tourism Trends. Madrid. 
Zurub, H. H, Ionescu, A., Constantin, V. D. 2015. Measuring the Economic Impact of Tourism in European Emerging Markets. Procedia Economics and Finance 32, 95-96.

\section{訬訬訬}

Internet 1: https://b65b2abo-1382-4437-8979-39ee56b39689.filesusr.com/ugd/o222ec dob3f86ob70a4967860aa1d51ecf6365.pdf (1.3.2020)

Internet 2: https://ec.europa.eu/eurostat/statistics-explained/index.php?title=Tourism industries - economic analysis\%20 (23.2.2020.)

Internet 3: https://ec.europa.eu/eurostat/statistics-explained/images/2/27/ (5.4.2020)

Internet 4: https://ec.europa.eu/eurostat/statistics-explained/images/e/e8/ (15.4.2020)

Internet 5: https://ec.europa.eu/eurostat/statisticsexplained/images/4/4c/Turnover or gross premiums written $\% 2 \mathrm{C} 2016 \% 28$ in million EUR\%29.png (23.2.2020)

Internet 6: https:/ec.europa.eu/eurostat/statisticsexplained/images/b/bb/Value added at factor cost\%2C $2016 \% 28$ in million EUR\%29.png (23.2.2020)

Internet 7: https://ec.europa.eu/eurostat/statistics-explained/pdfscache/34961.pdf (3.4.2020)

Internet 8: https://appsso.eurostat.ec.europa.eu/nui/show.do?dataset=tour dem extot\&lang=en $(29.2 .2020)$

Internet 9: https://unwto.org/international tourism (4.3.2020)

Internet 10: https://www.wttc.org/datagateway (14.4.2020) 